\title{
STRATEGI DAKWAH DALAM MENGANTISIPASI KRISIS AQIDAH
}

\author{
Oleh : Al Asy'ari
}

\begin{abstract}
Abstrak
Kondisi krisis sesungguhnya bukanlah muncul tanpa sebab atau adanya faktor-faktor yang mendorong tumbuh suburnya krisis dalam simpul batin seseorang yang disebut aqidah. Oleh sebab itu krisis aqidah dapat diantisipasi dengan berbagai upaya dakwah. Akan tetapi aqidah sebagai kondisi batin seseorang sudah pasti menemukan strategi khusus untuk mengantisipasi krisis akidah bagi individu muslim maupun kelompok
\end{abstract}

Kata Kunci: Strategi Dakwah dan Krisis Aqidah

\section{Gagasan Pembangunan Strategi Dakwah}

Aqidah merupakan simpulan batin seseorang terhadap Allah SWT yang memiliki sifat elastis dapat berubah dengan bertambah atau berkurang. Kondisi iman bagi seorang muslim sebagaimana diungkapkan dapat digolongkan dalam keadaan krisis. Dalam teori ajaran Islam iman seseorang di harapkan stabil. Kestabilan iman dimaksud akan sampai pada tingkat aqidah yang sesungguhnya. Kondisi seperti dikemukakan hampir dialami setiap muslim yang terkadang muncul sebagai prilaku dan implementasi dan kondisi aqidah yang mengalami krisis dalam kehidupan sesorang.

Sebelum mengungkap gagasan pembangunan strategi dakwah ada baiknya terlebih dahulu dijelaskan tentang strategi dakwah dalam seluruh aspek kehidupan manusia itu sendiri. Strategi perjuangan termasuk dakwah 
menyatakan, pendekatan muslim terhadap masalah perjuangan baik politik, sosial, dakwah, pendidikan dan lainnya, tetap profesionalisme meletakkan prinsip, strategi, taktik dan teknik perjuangan pada kedudukan masingmasing. Sehingga fungsi teknik menerangkan taktik, dan fungsi taktik untuk memenangkan strategi yang setiap saat dapat berubah. Strategi dapat berubah apabila masa perjuangan tertentu telah berakhir atau tidak sesuai dengan masalah yang dihadapi. ${ }^{1}$

Dari uraian di atas, strategi dakwah yang digunakan dalam setiap kegiatan dakwah hendaknya disesuaikan dengan tujuan yang hendak dicapai dalam kegiatan dakwah. Dan untuk mencapai tujuan, tidak terlepas dari berbagai aspek saling berkaitan dengan dakwah seperti da'i, mad'u, media dat materi dakwah.

Dakwah merupakan kegiatan yang sangat dibutuhkan dalam mencapai tujuan kehidupan. Dalam kehidupan manusia memiliki berbagai tujuan hidup. Kondisi tersebut menyebabkan dakwah nnemiliki keragaman tujuan. Untuk mencapai tujuan yang beragam tersebut sudah barang tentu strategi dakwah yang digunakan akan berbeda-beda dan disaat demikianlah strategi dakwah dapat berubah-ubah sesuai dengan fungsinya masing-masing.

Untuk lebih jelasnya mengenai strategi dakwah ${ }^{2}$ mengemukakan bahwa strategi dakwah artinya sebagai metode, siasat, taktik atau manuvers yang digunakan dalam aktivitas (kegiatan) dakwah. Lebih lanjut dikatakannya strategi yang dipergunakan dalam usaha dakwah harus memperhatikan bebeapa azas dakwah antara lain :

1. Azas filosofis, azas ini terutama membicarakan masalah yang erat hubungannya dengan tujuan-tujuan yang hendak dicapai dalam proses atau dalam aktivitas dakwah.

2. Azas kemampuan dan keahli da'i (achievement and profesional).

3. Azas sosiologis, yaitu azas yang membahas masalah-masalah yang berkaitan dengan situasi dan kondisi sasaran dakwah. Misalnya politik pemerintah setempat, filosofi sasaran dakwah, sosio kultural sasaran dakwah dan sebagainya.

${ }^{1}$ Rais, Amin. 1994. Islam Aktual. Bandung: Rajawali Perss. hlm. 94

${ }^{2}$ Syukir, Asmuni.1994. Dasar-Dasar Strategi Dakwah Islam. Jakarta: Aksara. hlm.32 
4. Azas psycologis, azas ini membahas masalah-masalah yang erat hubungannya dengan kejiwaan manusia. Seorang da'i adalah manusia begitupun sasaran dakwah memiliki karakter kejiwaan yang unik yakni berbeda satu lama lainnya. Apalagi masalah agama yang merupakan masalah idiologi atau kepercayaan (rohaniyah) tak luput dari masalah-masalah psyicologis sebagai dasar dakwahnya.

5. Azas epektivitas dan efisiensi, azas ini maksudnya adalah di dalam aktivitas dakwah harus menyeimbangkan antara biaya, waktu maupun tenaga yang dikeluarkan dengan pencapaian hasilnya, biaya dan tenaga yang sedikit dapat memperoleh hasil-hasil semaksimal mungkin. ${ }^{3}$

Menilik kepada perkembangan zaman dam kemajuan modern, sebagai hasil karya dari daya pikir manusia, tak dapat dibayangkan bahwa kehidupan manusia pada masa-masa mendatang akan jauh lebih mampu dari apa yang diperoleh pada masa lampau maupun masa sekarang. Tetapi apakah manusia akan lebih beriman pada masa mendatang, hal ini adalah soal lain, karena kemajuan dalam bidang ilmu pengetahuan yang dimiliki umat manusia pada dasarnya memiliki makna ganda bagi kehidupannya.

Kemajuan ilmu pengetahuan bisa menambah iman dan rasa syukur manusia kepada Tuhannya atau malah sebaliknya keimanan dan aqidahnya akan mengalami krisis bahkan memungkinkan untuk hilang sama sekali dalam diri manusia itu sendiri, atau membuatnya lupa dan pada akhirnya muncul ketakabburan dirinya terhadap Tuhan yang menciptakannya. Sebab penemuan dalam bidang alat-alat telah mampu memproduksi segala kebutuhan hidup manusiawi dalam kehidupannya. Padahal semua itu tidak dapat menjamin kebahagiaan hidup manusia.

DR. Yusuf Qadhawy mengemukakan pendapat seorang pujangga Barat yang namanya tidak disebutkan sebagai bahwa manusia dalam perjuangannya dengan alam sesungguhnya telah mencapai kemenangan dengan sejuta ilmu pengetahuan. Tetapi dalam berjuang melawan hawa nafsunya sendiri, belum mengarah kepada kemenangan, sedang sejuta ilmu pengetahuan tidak dapat menolongnya. Diakui bahwa hanya agama

${ }^{3}$ Ibid. hlm. 32-33 
yang dapat dijadikan kawan dalam perjuangan ini (melawan pengaruh nafsu). ${ }^{4}$

Hal ini sejalan dengan firman Allah dalam surah al-Jaatsiyah (QS. 45: 23) yang artinya:

Maka pernahkah kamu melihat orang yang menjadiknn hawa nafsunya sebagai tuhannya dan Allah membiarkannya sesat berdasarkan ilmunya, dan Allah telah mengunci mati pendengaran dan hatinya dan meletakkan tutupan penglihatannya. Maka siapakah yang akan memberikannya petunjuk sesudah Allah (membiarkannya sesat). Maka mengapa kamu tidak mengambil pelajaran ? ${ }^{5}$

Sesungguhnya sangat jelas dan tidak bisa diragukan lagi bahwa ilmu pengetahuan semata-mata tidak bisa memperbaiki jiwa manusia, sebab manusia selalu dipengaruhi hawa nafsu dan sahwatnya, baik secara pribadi maupun secara kelompok untuk mungikuti pendapat beberapa tokohnya. Padahal seharusnya manusia tunduk atas dorongan fitrahnya. Tunduk kepada sesuatu yang ada di atas pengetahuan manusia yang datang dari Tuhan, yakni agama. Akan tetapi di dunia ini tidak ada agama yang universal, sempurna kecuali Islam. Oleh karena itu hanya dengan keyakinan agama itulah, umat manusia akan dapat bebas dari segala penyakit kebendaan, politik, permusuhan, sosial dan sebagainya, yang kesemuanya ini membuat timbulnya krisis keyakinan dalam diri manusia itu sendiri.

Islam adalah agama yang merupakan sintesa, dari dua pandangan hidup, yaitu mementingkan dunia untuk meucapai tujuan akhirat. Dengan demikian dapat disimpulkan bahwa kesempurnaan Islam mencakup kehidupan manusia baik di dunia maupun di akhirat. Dalam penataan kehidupan dunia iman atau aqidah mempunyai peran yang sangat penting. Bila iman dan aqidah seseorang kalah dalam berbagai ujian dan cobaan yang dihadapinya, maka ia akan mudah menyeberang kesuatu persimpangan jalan. Akibatnya ia tidak akan mendapatkan kebahagiaan yang pada dasarnya terletak pada diri manusia itu sendiri.

Bahagia bukanlah terletak pada tumpukan harta, jabatan dan kemewahan

${ }^{4}$ Qardhawi, Yusuf. 1983. Masa Depan Islam. Jakarta : Al Kautsar. hlm. 73

${ }^{5}$ Depag RI. 1993. Al Qur'an dan Terjemahannya. Jakarta: Dirjend Depag. 
atau ilmu pengetahuan. Akan tetapi kebahagiaan itu suatu hal yang abstrak, tidak dapat dilihat indra manusia dan tidak dapat dibayar dengan imbalan apapun. Kebahagiaan hanya datang dari hati yang bersih, pikiran yang lapang, perasaan yang tenang dan keyakinan yang kuat dan kokoh kepada Allah SWT.

Aqidah dan keimanan yang kuat akan dapat menjiwai perbuatan manusia sebagai sumber kebahagiaan, ketentraman dan pengharapan. Dengan kata lain, imanlah yang menjadi kunci kebahagiaan lahir dan batin. Sebagaimana firman Allah dalani surah Ar-Ra'd (QS.13: 28) : Artinya : "Orang-orang yang beriman dan hati mereka menjadi tentram dengan mengingat Allah. Ingatlah, hanya dengan mengingat Allah-lah hati menjadi tentram"6

Saat ini betapa besarnya pengaruh illnu pengetahuan dan teknologi dalam kehidupan manusia. Namun ilmu tersebut tidak dapat menimbulkan ketentraman dan kebahagiaan bagi manusia, karena ia hanya meningkatkan segi materi semata dalam kehidupan manusia. Ilmu pengetahuan hanya mampu memberikan jalan kehidupan manusia. Alangkah ruginya manusia bila ia hanya disibukkan dengan jalan-jalannya saja, sementara ia buta akan tujuan dari ilmu pengetahuannya.

Jujun Suryasumantri dalam bukunya Ilmu Dalam Perspektifmengemukakan bahwa "mereka yang mendewa-dewakan ilmu sebagai satusatunya sumber kebenaran biasanya tidak mengetahui hakekat ilmu yang sebenarnya. Demikian juga sebaliknya dengan mereka yang memalingkan muka dengan ilmu, mereka yang tidak mau melihat kenyataan betapa ilmu telah membentuk peradaban seperti apa yang kita punyai sekarang ..."

Iman atau aqidah dalam diri seseorang sangat mempengaruhi seluruh sikap dan tingkah lakunya, sehingga bagaimanapun gelombang cobaan yang dihadapi seseorang akibat kemajuan zaman modern tidak akan mampu merubah keyakinan dan pendiriannya. Oleh karena itu, untuk mengantisipasi derasnya pengaruh dari kemajuan ilmu pengetahuan dan teknologi yang merupakan motor penggerak modernisasi. Untuk itu penerapan strategi dakwah yang tepat adalah yang paling dibutuhkan.

${ }^{6}$ Ibid. hlm.373

${ }^{7}$ Sumantri. 1994. Islam dan Pembaharuan Sosial. Jakarta: Persada. hlm.3 


\section{Strategi Dakwah di Tengah Tantangan Dakwah}

Memasuki abad ke-21 atau millenium ketiga, berbagai pihak sering melontarkan pendapat bahwa manusia sedang memasuki era modernisasi. Mungkin yang dimaksud, antara lain ialah era dimana kegiatan industri, atau pemanfaatan pengetahuan dan teknologi dihampir semua segi kehidupan manusia lebih mengemuka.

Suatu masa dimana orang sudah waktunya untuk berpola pikir dan berprilaku yang dinamis, seperti halnya dengan dinamika ilmu pengetahuan dan teknologi itu sendiri, sehingga ketergantunganya pada alam tak lagi bersifat kepasrahan pasif pada hukum-hukumnya. Sebab, sekarang saja seluruh bagian dunia seolah-olah telah lebur ke dalam suatu "desa global" (Global Village) meminjam istilannya Marshall Mc Luhan ${ }^{8}$

Proyek modernisasi dengan berbagai kemajuan dan kecanggihannya tentu mengalami perkembangan sehingga membuat manusia kian mampu memecahkan problema-problema kehidupannya. Namun mobilitas yang sangat tinggi akibat teknologi transpormasi, gaya hidup yang beragam yang digelarkan melalui media-media informasi dan komunikasi, membuat orang akan bersentuhan dengan nilai-nilai yang mungkin amat berbeda dengan apa yang dianutnya selama ini. Keadaan tersebut tentu membawa perubahan yang intensif bagi umat Islann dan merupakan permasalahan dakwah yang harus dijawab secara simultan dalam kerangka yang jelas.

Untuk mengantisipasi proses modernisasi, perlu dilaksanakan dakwah, riset dan analisa ilmiah dalam berbagai aspek dan struktur masyarakat. Selanjutnya meluruskan kebenaran dan dapat mewujudkan kemaslahatan umat manusia mengikuti petunjuk A1 Qur'an dan Hadist.

Dakwah dalam mengantisipasi semangat kebebasan harus melalui stuktur yang ada dalam masyarakat yang dilaksanakan secara rapi dan terorganisir. Apalagi proses modernisasi besar kemungkinan akan membawa manfaat kesejahteraan masyarakat dan merupakan pertanda jalannya aktualisasi dakwah dalam upaya menata masyarakat ditengah dinamika perubahan sosial. Aktualisasi dakwah bermakna dinamis dalam mengantisipasi

8Ibrahim. 1994. Prespektif Ajaran Islam dalam Era Global. Jakarta: Pustaka. hlm. 15 
proses modernisasi yang datang dari luar (Barat) dan mengadakan penyaringan terhadap budaya yang masuk. Abul A'la Maududi menyatakan : kita mesti melakukan penepisan terhadap budaya barat, mana yang bermanfaat dan mana yang berbahaya bagi segi moral, sistem kemasyarakatan dan pandangan hidup kita, kita kikis yang bathil, kita ambil yang bermanfaat, lalu kita cuci bersih seluruh kehidupan kita dari noda-noda seperti itu ${ }^{9}$

Secara esensi proses modernisasi adalah kesadaran dan kesengajaan untuk berubah. Terutama dalam artian transpormasi dan pembaharuan pola pikir setiap prilaku baik sebagai manusia individu, warga masyarakat, sekaligus sebagai hamba Allah SWT.

Upaya atau solusi yang dapat dilakukan dalam mengantisipasi tantangan modernisasi tersebut, paling tidak menurut Marwah Daud Ibrahim, ada lima strategi dakwah yang dapat dilakukan yaitu sebagai berikut :

1. Prinsif sinergi, berarti setiap da'i haruslah mempersiapkan bahwa apa yang ia lakukan hanya dapat lebih bermakna jika terintegrasi dengan yang lain.

2. Prinsif akumulasi berarti setiap yang ingin kita sampaikan perlu dilihat sebagai suatu proses akumulasi kebenaran-kebenaran relatif. Ini berarti apa yang kita sampaikan tidak harus selalu dipersiapkan sebagai langkah awal, tetapi merupakan perencanaan dan penyempurnaan dari langkah sebelumnya.

3. Prinsif konvergensi berarti bahwa walaupun kita berangkat dari tempat yang berbeda dan memakai jalan yang beragam, pada dasarnya kita menuju pada titik sentripetal yang sempurna yaitu tauhid.

4. Prinsip totalitas berati bahwa dakwah itu perlu dipersepsikan sebagai bermulti dimensi, dan semua dimensi harus disentuh.

5. Prinsip inklusivitas berarti bahwa kita harus melihat siapa saja sebagai bagian dari diri kita. Ini berarti bahwa dakwah sebaiknya dipersepsikan sebagai mediator yang efektif untuk menyatukan potensi-potensi umat yang selama ini terserak-serak ${ }^{10}$

${ }^{9}$ Maududi. 1984. Agama dan Negara. Suarabaya: Kentara Cipta. hlm. 170 ${ }^{10}$ Ibrahim. Of cit. hlm. 7-8 
Disisi lain Imam Musthafa Al-Maraghi dalam tafsirnya "Al Maraghi", Jilid 4 mengatakan bahwa idealnya seorang da'i wajib memenuhi empat syarat, sebagai upaya pemberhasilan dakwahnya, yaitu:

1. Wajib mempunyai kapabilitas pengetahuan dan pemahaman terhadap Al Quran dan Sunnah serta mengetahui sejarah Nabi Muhammad dan Khulafaur Rasyidin secara kredibel.

2. Wajib mengetahui keadaan daripada objek dakwah meliputi tradisi dan budaya serta prilaku etika dan akhlak mereka secara menyeluruh.

3. Wajib mengetahui dan memahami bahasa mereka secara baik dan benar.

4. Wajib mengetahui kecendrungan aliran dan tingkat pemahaman yang dianut dan difigurkan oleh para objek dakwah, karena dengan mengetahui keberadaan mereka dalam hal ini, akan lebih mudah diketahui kekurangan dan kelemahan yang notabene menjurus ke arah kebathilan yang telah biasa mereka lakukan, karena pada prinsiprya manusia itu sebelum mendapatkan penjelasan tentang sesuatu kebatilan yang ia lakukan sulit untuk menerima kenyataannya dan enggan diajak kearah kebenaran

Dari upaya di atas, secara implisit tergambar bahwa langkah awal dalam melakukan dakwah sangat diperlukan perencanaan. Hal ini dimaksudkan agar da'i tidak berfungsi sebagai faktor "sentripugal" (penentu dari pusat) sehingga seluruh missi dakwah tergantung kepadanya. Karenanya perencanaan dakwah harus lebih ditekankan agar berorientasi "sentripetal" yaitu berakar dari bawah.

Di sinilah kita berharap bahwa setiap orang, betapapun kecilnya usaha dakwah yang dilakukannya perlu dihargai dan dipersepsikan sebagai penyempurnaan dakwah yang lebih luas dan lebih besar. Dengan demikian diharapkan diantara umat Islam tidak mempersoalkan jalan apa yang ditempuh oleh mereka, karena semuanya terkonsentrasikan pada tujuan yang ingin dicapai yaitu titik pertemuan dari berbagai jalan (aliran, sudut pandangan, penekanan dan lain sebagainya).

Dalam konteks inilah dapat dipahami bahwa strategi dakwah itu sendiri bersifat general (keseluruhan) dan luas yang meliputi seluruh dimensi kebutuhan dan keinginan manusia, atau keseluruhan infra struktur yang 
diperlukan dalam menjalankan tugas kekhalifahan. Oleh karena itu strategi dan pendekatan dakwah yang menyeluruh dari sistematis kian terasa penting di era modernisasi yang menuntut kearah adanya spesialisasi. Dakwah yang kehilangan orientasi bisa membahayakan dari membawa kepada pemikiran yang picik dan sempit.

Dakwah dikatakan menghadapi tantangan besar bukan saja karena beragamnya tantangan dan intensitas perubaban zaman yang setiap kali memunculkan pertanyaan dan kajian baru. Tetapi juga mengingat multi dimensionalitas kebutuhan maupun kepentingan manusia yang kini cendrung lebih kritis akibat dari keluasan informasi dan pengalamannya. Kajian dakwah yang multidisipliner menjadi sangat dibutuhkan. Namun dalam era modernisasi peluang berdakwah juga menjadi besar, Jika iptek (teknologi komunikasi) dapat dipakai sebagai instrumen, bukan saja dalam penyelenggaraan kegiatan berdakwah, tetapi sekaligus dalam proses peyakinan akan kebesaran dan kemahaesaan Allah SWT.

Dalam konteks ini kegiatan berdakwah adalah bagaimana dengan rupa-rupa teknologi modern dan dalam gaya hidup modern, cinta kasih kepada Allah dan sesama manusia kian terasa. Itulah sebabnya dalam mengembangkan dakwah perlu dilakukan usaha dan strategi mengajak dan mengupayakan umat Islam untuk kembali menggali dan mengkaji sumber-sumber aslinya serta memulai untuk menerapkannya secara menyeluruh dalam kehidupan.

Langkah-langkah tersebut agaknya cukup dinamis dan universal serta tidak akan kering dan berhenti ibarat air sungai yang terus mengalir, yang takkan berhenti sebelum sampai kemuara. Sekalipun benar pada era modern sekarang ini :

Ajaran Islam harus didekatkan secara ilmiah dan rasional sehingga ajaran Islam bukan saja mudah dipahami dan diterima umat manusia, tetapi sekaligus melatih umat Islam menjadi lebih kritis dan cerdas gaya penalarannya dan lebih dari itu ajaran Islam atau hukum Islam akan diterima berdasarkan kesadaran ilmiah yang benar ${ }^{11}$

Strategi dakwah sebaiknya disusun atas dasar dari hasil-hasil pene-

${ }^{11}$ Amal. 1959. Islam Antara Pikir dan Zikir. Jakarta: Pustaka. hlm. 16 
litian. Hal itu perlu agar kegiatan dakwah dapat menyahuti kebutuhan yang diperlukan masyarakat. Di samping itu, dakwah juga diarahkan pada perluasan wawasan ke Islaman. Untuk itu perlu dikembangkan kegiatan interpretasi terhadap nash-nash Al Qur'an secara kreatif, aktual dan profesional.

Masa depan dakwah idealnya ditentukan oleh kemampuan umat Islam hari ini untuk mengembangkannya serta mempraktekkannya sesuai dengan realitas dan kondisi dari perubahan masyarakat yang ada. Intinya bahwa dakwah Islam tetap memunculkan konsep-konsep Islam sebagai suatu agama yang dapat membawa kemajuan dan perbaikan masyarakat demi mencapai kebahagiaan hidup di dunia dan di akhirat.

\section{Dakwah Bil-Hal Suatu Alternatif}

Dakwah Islam adalah mengajak manusia dengan cara bijaksana kepada jalan yang benar sesuai dengan perintah Tuhan, untuk kemaslahatan dan kebahagiaan mereka di dunia dan di akhirat ${ }^{12}$. Selanjutnya menurut K.H.M. Anshary, dakwah islamiyah merupakan upaya menyampaikan seruan Islam, mengajak dan, memanggil umat manusia agar menerima dan mempercayai keyakinan dan pandangan hidup Islam ${ }^{13}$

Islam sebagai agama dakwah adalah agama yang menugaskan umatnya untuk menyeru dan mengajak seluruh umat manusia supaya menerima dan mempercayai keyakinan dan pandangan hidup Islam secara kaffah (keseluruhan). Tugas dakwah dalam menyampaikan ajaran Islam kepada seluruh umat manusia merupakan kewajiban yang harus dilakukan kapan dan dimana saja. Dalam ajaran Islam, dakwah tidak mengenal istilah berhenti untuk disampaikan kepada umat manusia.

Pelaksanaan dakwah yang pada akhirnya menyadarkan manusia sebagai makhluk ciptaan Allah, yang berfungsi sebagai khalifah Allah dimuka bumi ini. Tujuan sentral dakwah itu sendiri yaitu dengan terwujudnya kebahagiaan dan kesejahteraan hidup di dunia dan di akhirat yang diridhoi Allah SWT ${ }^{14}$

${ }^{12}$ Omar. 1955. Perjalanan Dakwah Rasul. Surabaya: Cipta Karya. hlm. 1

${ }^{13}$ Ansyari. 1991. Dakwah Islamiyah. Jakarta: Penermit Raya. hlm. 17

${ }^{14}$ Shale. Abd. Rosyad. Manajemen Dakwah Islam. Jakarta: Rosyda Karya. hlm. 21 
Sejalan dengan perubahan dan perkembangan zaman yang begitu cepat dan global, maka kondisi dakwah Islam harus melakukan perubahanperubahan dan perubakan sesuai dengan laju perkembangan zaman. Hal ini dapat dilakukan asal tidak menyimpang dari konteks Al Quran dan Hadits sebagai pedoman dan acuan pelaksanaannya. Dakwah bisa dikatan berhasil apabila benar-benar menyentuh apa yang diinginkan oleh masya-rakat yang membutuhkannya. Disamping itu kehadiran dakwah harus benar-benar mampu menjembatani, merespon dan memberikan jalan keluar yang tepat terhadap berbagai persoalan yang terjadi di tengahtengah masyarakat.

Aktivitas dakwah Islam meliputi berbagai dimensi hidup dan kehidupan manusia, karena pada dasarnya pelaksanaan amar ma'ruf nahi munkar meliputi kehidupan yang multi dimensional. Amar nia'ruf nahi munkar artinya memerintahkan ma'ruf dan melarang munkar. Munkar adalah apa saja yang dipandang buruk, diharamkan dan dibenci oleh syara'. Sedangkan ma'ruf adalah apa saja yang dipandang baik, diperintahkan dan dianjurkan syara'15

Kewajiban mengajak manusia berada kejalan Allah, merupakan kewajiban setiap pribadi Muslim. Namun karena dalam masyarakat terdapat kompleksitas masalah, sehingga usaha-usaha dakwah tidak akan efektif jika dilakukan secara individual. Oleh karenanya dalam Al Qur'an dijelaskan bahwa untuk menegakkan kebenaran dan keadilan serta mencegah kedzaliman, sesama Muslim diharuskan untuk bekerjasama. Untuk itu tentunya perlu adanya realisasi pelembagaan, artinya nilai-nilai yang diperoleh dalam proses pelembagaan dakwah kemudian perlu untuk dilembagakan dalam sebuah sistem yang benar-benar kokoh. Pelembagaan yang dimaksud adalah pelembagaan Islam dalam kehidupan usrah, jema'ah umat sebagai proses institusional.

Ingatlah bahwa Allah sangat menganjurkan setiap muslim untuk mengorganisir diri sehingga menjadi sebuah ikatan dan bangunan yang berdiri kokoh dan menjadi kuat. Firman Allah dalam surah Ash-Shaff (QS. 61:4). "Sesungguhnya Allah menyukai orang-orang yang berperang dijalan- 
Nya dalam barisan yang teratur seakan-akan mereka seperti bangunan yang tersusun kokoh" 16

Dakwah pada pokoknya berarti ajakan atau panggilan yang diarahkan pada masyarakat luas untuk menerima kebaikan dan mening-galkarn keburukan. Dakwah merupakan usaha untuk menciptakan situasi yang lebih baik sesuai dengan ajaran-ajaran Islam disemua bidang kehidupan. Dipandang dari kacamata dakwah, kehidupan manusia dapat dibedakan dari berbagai segi, tetapi dalam kenyataannya kehidupan itu tidak dapat dipisah-pisahkan Dalam menyahuti kebutuhan masyarakat terhadap arti penting yang tengah dijalankan dari waktu ke waktu, paling tidak untuk mengatasi berbagai bentuk kekurangan dan ketidak merataan pelaksanaan dakwah ditengah masyarakat yang cendrung dilanda gerakan modernisasi dan pembangunan teknologi diberbagai bidang kehidupan, setidaknya bisa ditempuh melalui dua jalan. Pertama : memberi motivasi kepada kaum muslimin yang mampu untuk menumbuhkan solidaritas sosial, yang akhir-akhir ini ada kecendrungan menurun dikalangan umat. Kedua: Yang paling mendasar adalah dakwah dalam bentuk aksi-aksi nyata dan program-program yang langsung menyentuh kebutuhan. Inilah yang sering disebut dengan dakwah bil-hal.

Dakwah bil-hal merupakan bentuk dakwah yang berusaha menyiarkan ajaran Islam kepada manusia dan masyarakat dengan cara merealisasikan ajaran Islam kedalam bentuk yang nyata. Secara sempit dakwah bil-hal dapat direalisasikan dan diwujudkan dengan jalan menampilkan prilaku dan tata cara hidup dalam kehidupan sehari-hari. Sedangkan secara umum dakwah bil-hal direalisasikan dengan cara mendirikan atau membentuk berbagai sarana kehidupan sosial masyarakat, seperti sekolah/madrasah, rumah ibadah, lembaga ekonomi, proyek percontohan, balai latihan kerja, biro jasa dan lain sebagainya, sesuai dengan kebutuhan masyarakat sebagai objek dakwah.

Sejak Nabi Muhammad diangkat menjadi Rasulullah, beliau telah memperaktekkan dakwah bil-hal yaitu dengan memberikan uswatun hasanah, baik dalam perbuatan maupun dalam bentuk tingkah laku dan perbuatan. Sejarah mencatat bahwa dengan cara memberi uswatun hasanah kepada manusia Nabi Muhammad SAW berhasil menarik simpati umat lain. Dengan

${ }^{16}$ Depag RI. Loc Cit. hlm. 928 
cara ini pula akhirnya mereka menerima ajaran Islam tanpa ada rasa paksaan dan desakan dari siapapun.

Dakwah bil-hal memang merupakan bentuk dakwah yang efektif dalam upaya menerapkan ajaran Islam dalam kehidupan manusia. Hal ini karena manusia akan lebih mudah menerima suatu ajaran yang diwujudkan dalam bentuk nyata ketimbang disampaikan dalam bentuk konsep atau sekedar teori-teori belaka. Dakwah bil-hal akan dapat menimbulkan simpati orang lain dan mendorong manusia untuk menirunya, sekaligus menerimanya sebagai suatu bagian yang harus diamalkan dan dilaksanakan dalam kehidupannya, baik secara individu maupun kelompok.

Dakwah bil-hal menurut sebagian orang merupakan koreksi terhadap dakwah yang selama ini banyak terfokus pada dakwah "mimbar" yang terkesan monoton dari sisi penerima dan pembicaraannya, semen-tara dana dan daya yang tersedia habis untuk kegiatan tanpa ada perubahan yang cukup berarti. Sebaliknya dakwah bil-hal seperti pemahaman kebanyakan orang adalah dakwah pembangunan, yang melakukan aksi-aksi nyata dalam proscs perubahan masyarakat menuju kemajuan, artinya bersifat progresif bahkan revolusioner.

Dakwah tidak akan dapat menerima status quo yang bertentangan dengan tuntunan wahyu atau ajaran-ajaran agama. Dakwah merupakan gerakan simultan dan rekonstruksi masyarakat sesuai dengan ajaran Islam dalam berbagai bidang kehidupan untuk memasyarakatkan Islam sebagai agama (ad-din), sebagai pandangan hidup dan paradigma bagi pemecahan masalah. Untuk masyarakat Indonesia, Amien Rais (menyarankan bahwa perubahan normatif jauh lebih relevan dan realistis serta lebih produktif, sehingga kegiatan Dakwah di bidang apapun harus dirancang sesuai dengan kondisi masyarakat Indonesia. ${ }^{17}$

Quraish Shihab dalam bukunya Membumikan Al Qur'an menjelaskan bahwa dakwah bil-hal adalah dakwah pembangunan, dakwah dengan keteladanan dalam berbagai kegiatan nyata lainnya yang memerlukan aksi sosial ${ }^{18}$. Kemudian Amien Rais mengemukakan dakwah bil-hal pada

\footnotetext{
${ }^{17}$ Rais. Amin. 1991. Cakrawala Islam. Bandung: Mizan. hlm. 26-27 18Shihab. Quraish. 1991. Membumikan Al Qur'an. Bandung: Mizan. hlm. 398.
} 
hakekatnya merupakan perwujudan dari dakwah lisan dan dakwah bil kitabah, yang menyangkut seluruh segi kehidupan. Adapun tujuan dakwah bil-hal antara lain untuk meningkatkan harkat dan martabat terutama kaum dhuafa atau kaum yang berpenghasilan rendah. ${ }^{19}$

Dari tujuan yang dikemukakan di atas menunjukkan bahwa tujuan dakwah bil-hal diharapkan dapat membantu orang-orang lemah atau berpenghasilan rendah, sehingga proses keteladanan Islam untuk saling membantu dan tolong menolong dapat direalisasikan. Quraish Shihab menyebutkan, Dakwah bil-hal diharapkan dapat menunjang segi kehidupan masyarakat, sehingga pada akhirnya setiap komunitas memiliki kemampuan untuk mengatasi kebutuhan dan kepentingan anggotanya, khususnya dalam bidang ekonomi, pendidikan, kesehatan masyarakat. ${ }^{20}$

Dengan melakukan kegiatan dakwah bil-hal atau bil hikmah, bukan berarti dakwah bil lisan atau mu'idzah hasanah ditinggalkan. Dakwah model mauidhah hasanah atau dakwah lewat mimbar tetap perlu dalam konteks tertentu, misalnya khatib jum'at, ceramah-ceramah agama dan lain sebagainya. Juga tidak ditinggalkan cara berdakwah mujadalah yang lebih efisien seperti dalam forum dialog, seminar, simposium atau diskusidiskusi.

Dakwah bil-hal juga bisa dilakukan dalam bentuk pengembangan masyarakat. Adapun pengembangan masyarakat atau pemberdayaan rakyat adalah proses dari serangkaian kegiatan yang mengarah kepada peningkatan taraf hidup dan kesejahteraan masyarakat. Proses tersebut mengandung kegiatan yang diharapkan dapat mengubah dan mengembangkan sikap, gaya hidup, pola berpikir serta meningkatkan kesadaran masyarakat. Shahal Mahfudf mengemukakan bahwa usaha dakwah bilhal mempunyai implikasi terhadap pengembangan masyaraka yaitu :

1. masyarakat yang menjadi sasaran dakwah, pendapatannya bertambah untuk membiayai pendidikan keluarga atau memperbaiki kesehatan.

2. Dapat menarik partisipasi masyarakat dalam pembangunan, sebab masyarakat terlibat sejak perencanaan sampai pelaksanaan usaha dakwah bil -hal.

${ }^{19}$ Hamka. 1990. Ilmu Dakwah. Jakarta: Pustaka. hlm. 316

${ }^{20}$ Shihab. Quraish. 1991. Op Cit. hlm. 398 
3. Dapat mengembangkan kepemimpinan daerah setempat dan terkelolanya sumber daya manusia yang ada. Sebab anggota kelompok sasaran tidak saja jadi objek kegiatan, tetapi juga menjadi subjek kegiatan.

4. Terjadinya proses belajar mengajar antara sesama warga yang terlibat dalam kegiatan. Sebab kegiatan direncanakan dan dilakukan secara bersama. Hal ini menimbulkan adanya sumbang saran secara timbal balik

Salah satu isyarat dakwah adalah bukan saja mengajak orang lain untuk menerima namun juga mengubah, dalam arti mengubah tingkah laku dan gagasan sehingga akan memperoleh keselamatan. Oleh karenanya, kata Islamisasi merupakan kata kerja yang selalu identik dengan dakwah. Kata dakwah sangat identik dengan pembangunan, untuk menjelaskan bahwa dakwah itu tidak saja mengajak orang untuk menerima Islam tetapi juga harus mampu melakukan perubahan.

Lebih lanjut Mukti Ali dalam bukunya Memahami Beberapa Aspek Islam, menyarankan bahwa yang perlu dilakukan adalah aksi sosial dilapangan, sebagaimana dikatakannya :

Melalui dorongan iman dan moral keagamaan yang ditranspormasikan dalam amal dan aksi untuk pembangunan diharapkan terjadi tidak saja proses perubahan sosial, tetapi juga proses perubahan kehidupan dan pemikiran keagamaan, yang secara dinamis akan saling menunjang pembangunan manusia modern seutuhnya ${ }^{21}$

Dari uraian-uraian di atas, dapat disimpulkan bahwa dakwah bilhal secara konkrit merupakan rekonstruksi masyarakat sesuai dengan ajaran Islam. Dalam upaya rekonstruksi tersebut, proses perubahan yang dilakukan haruslah berencana dengan sasaran yang jelas dapat membawa perubahan secara intensif dan dapat menyentuh nilai-nilai yang paling fundamental bagi umat Islam. hlm. 135

${ }^{21}$ Ali. Mukti. 1991. Memahami Beberapa Aspek Islam. Jakarta: Persada. 


\section{Penutup}

Upaya mengantisipasi krisis aqidah dalam kehidupan masyarakat Islam telah memiliki petunjuk dasar dalam A1 Qur'an Nul Karim. Tetapi diperlukan berbagai azas untuk menunjang strategi dakwah dalam mengantisipasi krisis aqidah seperti azas filosofis, achievemant, sosiologis, psikologis dan azas efektivitas, sehingga proses dakwah dapat menemukan strategi yang mapan dan berhasil guna.

Setiap langkah strategi memerlukan prinsip dasar yakni prinsip sinergi, akumulasi, konvergensi, totalitas dan prinsip inklusivitas. Dengan prinsip-prinsip dasar tersebut dapat diharapkan strategi dakwah dalam mengantisipasi krisis atau kelabilan aqidah dalam kehidupan masyarakat akan dapat diwujudkan dalam implementasi yang sesuai dengan tuntutan dakwah dalam membina aqidah yang stabil. 


\section{DAFTAR PUSTAKA}

Rais, Amin. 1994. Islam Aktual. Bandung: Rajawali Perss.

Syukir, Asmuni.1994. Dasar-Dasar Strategi Dakwah Islam. Jakarta: Aksara Qardhawi, Yusuf. 1983. Masa Depan Islam. Jakarta : Al Kautsar Depag RI. 1993. Al Qur'an dan Terjemahannya. Jakarta: Dirjend Depag. Sumantri. 1994. Islam dan Pembaharuan Sosial. Jakarta: Persada. Ibrahim. 1994. Prespektif Ajaran Islam dalam Era Global. Jakarta: Pustaka Maududi. 1984. Agama dan Negara. Suarabaya: Kentara Cipta Amal. 1959. Islam Antara Pikir dan Zikir. Jakarta: Pustaka Omar. 1955. Perjalanan Dakwah Rasul. Surabaya: Cipta Karya Ansyari. 1991. Dakwah Islamiyah. Jakarta: Penermit Raya Shale. Abd. Rosyad. Manajemen Dakwah Islam. Jakarta: Rosyda Karya Rais. Amin. 1991. Cakrawala Islam. Bandung: Mizan.

Shihab. Quraish. 1991. Membumikan Al Qur'an. Bandung: Mizan Hamka. 1990. Ilmu Dakwah. Jakarta: Pustaka Ali. Mukti. 1991. Memahami Beberapa Aspek Islam. Jakarta: Persada 